\section{Stability of Extemporaneously Compounded Trimethoprim in Glass and Plastic Bottles and Plastic Syringes}

This study evaluated the physical and chemical stability of trimethoprim suspension in commercially available dye-free vehicles at $25^{\circ} \mathrm{C}$ and $4^{\circ} \mathrm{C}$ in various containers for up to 92 days.

Stock suspensions of trimethoprim $10 \mathrm{mg} / \mathrm{mL}$ were prepared by crushing trimethoprim 100-mg tablets (AA Pharma Inc, Concord, Ontario; lot KW8605, expiry April 2016) in 400-mL volumes of each of Oral Mix and Oral Mix SF (Medisca Pharmaceutique Inc, Montréal, Quebec; lot I185/A, expiry January 2018, and lot H1136, expiry October 2017, respectively). Each suspension was divided among 6 amber glass bottles (Richards Distribution, Richmond, British Columbia), 6 amber polyethylene terephthalate prescription bottles (Richards Distribution), and twenty-five 3-mL amber plastic oral syringes (PreciseDose Dispenser System, Medisca Pharmaceutique Inc; lot 601979R/E). Three glass and 3 plastic bottles of each suspension were kept at $25^{\circ} \mathrm{C}$, and the remaining bottles at $4^{\circ} \mathrm{C}$. All syringes were kept at $25^{\circ} \mathrm{C}$.

All samples were examined for colour, odour, taste, and ease of resuspension on days 0 (baseline), 7, 14, 21, 28, 42, 63, 77, and 92. On each study day, one 3-mL aliquot from each bottle and the contents of 3 syringes from each group were collected to determine $\mathrm{pH}$ ( $\mathrm{pH}$ meter model 800, VWR International, Mississauga, Ontario). A $1.5-\mathrm{mL}$ aliquot from each bottle or syringe was transferred to a threaded, tight-seal cryogenic polypropylene vial (VWR International; lot 1095990$)$ and frozen $\left(-85^{\circ} \mathrm{C}\right)$ until analysis by a validated, stability-indicating high-performance liquid chromatography (HPLC) - ultraviolet detection method. ${ }^{1-3}$

Stock solutions of trimethoprim $10 \mathrm{mg} / \mathrm{mL}$ were prepared from trimethoprim powder (Sigma-Aldrich, Oakville, Ontario; lot BCBN2518V, no expiry) in Oral Mix SF (Medisca Pharmaceutique; lot H1136, expiry October 2017) to construct standard curves. Naproxen powder (Sigma-Aldrich; lot SLBH7957V, no expiry) diluted to $0.20 \mathrm{mg} / \mathrm{mL}$ in HPLC-grade methanol (Fisher Scientific, Whitby, Ontario; lot 155002, no expiry) served as the internal standard. Trimethoprim standards containing $0.02 \mathrm{mg} / \mathrm{mL}$ internal standard were prepared in HPLC-grade methanol to final concentrations of $0.050,0.070,0.090,0.110,0.130$, and $0.140 \mathrm{mg} / \mathrm{mL}$, with quality controls of $0.050,0.080,0.100$, and $0.120 \mathrm{mg} / \mathrm{mL}$. Each sample was passed through a Gelman hydrophilic propylene $13-\mathrm{mm}$ diameter, $0.45-\mu \mathrm{m}$ microfilter (Acrodisc, Waters Corporation, Mississauga, Ontario; lot 21829235). Standard curves were generated by least-squares regression of the peak-area ratio of trimethoprim to internal standard and the concentration of each trimethoprim standard.

The HPLC instrumentation (Waters Alliance System model 2690, Waters Corporation) consisted of a delivery pump, automated 200- $\mu \mathrm{L}$ injector, XTerra RP18 $4.6 \times 150 \mathrm{~mm}$ column (Waters Corporation; lot 01803336513887), XTerra RP18 $3.9 \times$ $20 \mathrm{~mm}$ guard column (Waters Corporation; lot 0184352501), and ultraviolet detector set at $225 \mathrm{~nm}$. The mobile phase consisted of $76 \%$ methanol and $24 \% 10 \mathrm{mmol} / \mathrm{L}$ ammonium formate buffer (Sigma-Aldrich; lot BCBL4456V) at $\mathrm{pH} 4.0$ and $25^{\circ} \mathrm{C}$. All solvents were HPLC-grade and filtered before use. Flow rate was $0.8 \mathrm{~mL} / \mathrm{min}$.

On analysis days, samples were thawed and vortex-mixed. A $0.2-\mathrm{mL}$ aliquot from each thawed sample was diluted with $1.8 \mathrm{~mL}$ of HPLC-grade methanol and centrifuged at $5200 \mathrm{rpm}$ for $5 \mathrm{~min}$. Supernatant $(100 \mu \mathrm{L})$ was diluted to a final nominal concentration of $0.100 \mathrm{mg} / \mathrm{mL}$ in HPLC-grade methanol containing 0.0200 $\mathrm{mg} / \mathrm{mL}$ internal standard. Each sample $(10 \mu \mathrm{L})$ was filtered before injection onto the column.

For accelerated degradation, trimethoprim $2.0 \mathrm{mg} / \mathrm{mL}$ suspensions were prepared (without internal standard) from 100-mg trimethoprim tablets in Oral Mix and Oral Mix SF, mixed (v/v) with water, $2 \mathrm{~N}$ hydrochloric acid, $2 \mathrm{~N}$ sodium hydroxide, and $10 \%$ hydrogen peroxide, then vortex-mixed and incubated for $18 \mathrm{~h}$ at $60^{\circ} \mathrm{C}$; after incubation, the water samples were boiled for $2 \mathrm{~min}$. All samples were cooled to $25^{\circ} \mathrm{C}$ and centrifuged. Supernatant $(0.2 \mathrm{~mL})$ was diluted in HPLC-grade methanol to $0.10 \mathrm{mg} / \mathrm{mL}$, filtered, and injected onto the column.

Regression analysis showed coefficients of determination $\left(r^{2}\right)$ above $0.997(n=4)$. Intraday and interday coefficients of variation for quality control samples were $1.43 \%$ and $2.63 \%$, respectively, for $0.050 \mathrm{mg} / \mathrm{mL}$ solution; $0.59 \%$ and $0.86 \%$, respectively, for $0.080 \mathrm{mg} / \mathrm{mL}$ solution; $0.89 \%$ and $1.18 \%$, respectively, for $0.100 \mathrm{mg} / \mathrm{mL}$ solution; and $1.07 \%$ and $1.18 \%$, respectively, for $0.120 \mathrm{mg} / \mathrm{mL}$ solution. Intraday and interday accuracy values (mean \pm standard deviation) were $97.74 \% \pm 0.60 \%$ and $97.27 \% \pm 1.53 \%$, respectively, for $0.050 \mathrm{mg} / \mathrm{mL}$ solution; $99.27 \% \pm 0.74 \%$ and $99.15 \% \pm 0.64 \%$, respectively, for $0.080 \mathrm{mg} / \mathrm{mL}$ solution; $99.16 \% \pm 0.71 \%$ and $99.06 \% \pm 0.91 \%$, 
Table 1. Concentration of Trimethoprim in Oral Mix Suspension Vehicle During 92 Days of Storage in Glass Bottles, Plastic Bottles, and Plastic Syringes at $25^{\circ} \mathrm{C}$ and in Glass and Plastic Bottles at $4^{\circ} \mathrm{C} *$

Mean Concentration \pm SD $(\mathrm{mg} / \mathrm{mL})$ and Mean \% Remaining

\begin{tabular}{|c|c|c|c|c|c|c|}
\hline & & & & & & \\
\hline Study Day & Glass Bot & & Plastic Bo & les & Plastic S & nges \\
\hline $25^{\circ} \mathrm{C}$ storage & & & & & & \\
\hline 0 & $9.97 \pm 0.58$ & & $9.97 \pm 0.58$ & & $9.97 \pm 0.58$ & \\
\hline 7 & $9.64 \pm 0.27$ & (96.6) & $9.68 \pm 0.08$ & $(97.1)$ & $9.82 \pm 0.06$ & (98.5) \\
\hline 14 & $9.94 \pm 0.19$ & (99.6) & $9.79 \pm 0.16$ & $(98.1)$ & $9.82 \pm 0.25$ & (98.4) \\
\hline 21 & $9.88 \pm 0.21$ & (99.0) & $9.85 \pm 0.06$ & (98.8) & $9.82 \pm 0.32$ & (98.5) \\
\hline 28 & $9.82 \pm 0.13$ & $(98.4)$ & $9.95 \pm 0.14$ & (99.8) & $9.77 \pm 0.16$ & (99.7) \\
\hline 42 & $9.81 \pm 0.27$ & (98.3) & $9.67 \pm 0.27$ & $(97.0)$ & $9.82 \pm 0.18$ & (98.4) \\
\hline 63 & $9.57 \pm 0.12$ & (95.9) & $9.76 \pm 0.35$ & (97.9) & $9.77 \pm 0.17$ & (97.9) \\
\hline 77 & $9.63 \pm 0.10$ & (99.9) & $9.97 \pm 0.16$ & $(100.0)$ & $9.86 \pm 0.23$ & (98.9) \\
\hline 92 & $9.55 \pm 0.20$ & $(95.7)$ & $9.82 \pm 0.13$ & $(98.5)$ & $9.78 \pm 0.20$ & (98.1) \\
\hline $\begin{array}{l}\text { \% remaining on day } 92 \\
\text { by linear regressiont }\end{array}$ & 97.9 & & 100.2 & & 99.2 & \\
\hline $\begin{array}{l}\text { Lower limit of } 95 \% \mathrm{Cl} \text { for } \\
\% \text { remaining } \neq\end{array}$ & 94.1 & & 97.2 & & 97.8 & \\
\hline$\overline{4^{\circ} \mathrm{C} \text { storage }}$ & & & & & $\mathrm{NA}$ & \\
\hline 0 & $9.97 \pm 0.58$ & & $9.97 \pm 0.58$ & & & \\
\hline 7 & $9.95 \pm 0.15$ & (99.8) & $9.95 \pm 0.10$ & (99.7) & & \\
\hline 14 & $9.83 \pm 0.24$ & (98.5) & $9.89 \pm 0.46$ & $(99.2)$ & & \\
\hline 21 & $9.76 \pm 0.08$ & $(97.8)$ & $9.91 \pm 0.23$ & (99.4) & & \\
\hline 28 & $9.82 \pm 0.22$ & $(98.5)$ & $9.88 \pm 0.25$ & (99.0) & & \\
\hline 42 & $9.90 \pm 0.21$ & (99.3) & $10.05 \pm 0.36$ & $(100.7)$ & & \\
\hline 63 & $9.74 \pm 0.25$ & $(97.6)$ & $9.62 \pm 0.12$ & $(96.4)$ & & \\
\hline 77 & $9.86 \pm 0.31$ & $(98.8)$ & $9.84 \pm 0.24$ & $(98.6)$ & & \\
\hline 92 & $9.65 \pm 0.36$ & $(96.8)$ & $9.82 \pm 0.23$ & $(98.5)$ & & \\
\hline $\begin{array}{c}\% \text { remaining on day } 92 \\
\text { by linear regressiont }\end{array}$ & 98.0 & & 98.1 & & & \\
\hline $\begin{array}{l}\text { Lower limit of } 95 \% \mathrm{Cl} \text { for } \\
\% \text { remaining } \neq\end{array}$ & 96.0 & & 95.6 & & & \\
\hline $\begin{array}{l}\mathrm{Cl}=\text { confidence interval, } \mathrm{N} / \\
{ }^{*} \text { Nominal concentration: } 10 \\
\text { measured concentration on } \\
\text { †Calculated from concentra } \\
\text { according to the following } \\
\text { †Calculated from lower lim } \\
\text { according to the following }\end{array}$ & $\begin{array}{l}\text { ble, } S D=\text { sta } \\
\text { an values be } \\
\text { as determi } \\
\text { the slope o } \\
\text { the limit of } 95\end{array}$ & $\begin{array}{l}\text { rd devia } \\
\text { on } 3 \text { sa } \\
\text { by linea } \\
92 \div \text { co } \\
\text { curve r }\end{array}$ & $\begin{array}{l}\text { analyzed in d } \\
\text { ssion and con } \\
\text { ation at time } \\
\text { concentratio }\end{array}$ & $\begin{array}{l}\text { licate. Pe } \\
\text { ntration } \\
\times 100 . \\
\text { to time, } \\
\text { concentr }\end{array}$ & $\begin{array}{l}\text { naining relat } \\
\text { at time } 0 \text {, } \\
\text { ed by linear } \\
\text { time } 0) \times 10\end{array}$ & to \\
\hline
\end{tabular}

respectively, for $0.100 \mathrm{mg} / \mathrm{mL}$ solution; and $99.38 \% \pm 0.40 \%$ and $99.12 \% \pm 0.85 \%$, respectively, for $0.120 \mathrm{mg} / \mathrm{mL}$ solution.

Retention times were $2.15 \mathrm{~min}$ for trimethoprim and $4.02 \mathrm{~min}$ for the internal standard. With forced degradation, no interfering peaks were generated; the trimethoprim peak decreased by $19.2 \%-30.1 \%$ in Oral Mix and by $20.2 \%-26.3 \%$ in Oral Mix SF. Minor, non-interfering peaks were observed at 1.72, 2.47, 3.09, and $3.68 \mathrm{~min}$. Time 0 samples stored for 92 days at $-85^{\circ} \mathrm{C}$ showed no degradation products and contained the expected concentration of trimethoprim.

No precipitate formed up to day 63, at which point some granules were observed in the suspensions. All suspensions were easily resuspended. No notable changes in milky white colour, acidic taste, or sweet-cherry odour of suspensions occurred. Mean $\mathrm{pH}$ remained stable (6.04-6.11 in Oral Mix, 6.09-6.20 in Oral Mix SF).
HPLC analyses showed that all suspensions maintained more than $90 \%$ of their original concentration for up to 92 days (Tables 1 and 2).

In conclusion, trimethoprim suspensions $(10 \mathrm{mg} / \mathrm{mL})$ in Oral Mix and Oral Mix SF remained stable for up to 92 days in glass and plastic bottles $\left(25^{\circ} \mathrm{C}\right.$ or $\left.4^{\circ} \mathrm{C}\right)$ or syringes $\left(25^{\circ} \mathrm{C}\right)$.

\section{References}

1. Ghanem MM, Abu-Lafi SA. Validation of a stability-indicating RP-HPLC method for the simultaneous determination of trimethoprim and sulfadimethoxine sodium in oral liquid dosage form. Sci Pharm. 2013;81(2):459-74.

2. Ghanem MM, Abu-Lafi SA. Development and validation of a stabilityindicating HPLC method for the simultaneous determination of sulfadiazine sodium and trimethoprim in injectable solution formulation. Sci Pharm. 2013;81(1):167-82.

3. Ensom MHH, Décarie D, Lingertat-Walsh K. Stability of extemporaneously compounded naproxen $25 \mathrm{mg} / \mathrm{mL}$ suspension in glass and plastic bottles and plastic syringes. Can J Hosp Pharm. 2015;68(6):489-93. 
Table 2. Concentration of Trimethoprim in Oral Mix SF Suspension Vehicle During 92 Days of Storage in Glass Bottles, Plastic Bottles, and Plastic Syringes at $25^{\circ} \mathrm{C}$ and in Glass and Plastic Bottles at $4^{\circ} \mathrm{C}^{*}$

Mean Concentration \pm SD $(\mathrm{mg} / \mathrm{mL})$ and Mean \% Remaining

\begin{tabular}{|c|c|c|c|c|c|c|}
\hline \multirow{2}{*}{$\frac{\text { Study Day }}{25^{\circ} \mathrm{C} \text { storage }}$} & \multicolumn{2}{|c|}{ Glass Bottles } & \multicolumn{2}{|c|}{ Plastic Bottles } & \multicolumn{2}{|c|}{ Plastic Syringes } \\
\hline & & & & & & \\
\hline 0 & $9.84 \pm 0.10$ & & $9.84 \pm 0.10$ & & $9.84 \pm 0.10$ & \\
\hline 7 & $9.86 \pm 0.10$ & $(100.2)$ & $9.98 \pm 0.06$ & $(101.4)$ & $9.93 \pm 0.08$ & (100.9) \\
\hline 14 & $9.89 \pm 0.19$ & (100.5) & $9.77 \pm 0.10$ & (99.3) & $9.94 \pm 0.23$ & (101.1) \\
\hline 21 & $10.10 \pm 0.23$ & $(102.7)$ & $9.73 \pm 0.08$ & (98.9) & $9.88 \pm 0.20$ & $(100.4)$ \\
\hline 28 & $10.00 \pm 0.12$ & (101.6) & $9.91 \pm 0.11$ & (100.8) & $9.98 \pm 0.05$ & (101.4) \\
\hline 42 & $9.63 \pm 0.09$ & (97.9) & $9.56 \pm 0.07$ & (97.1) & $9.77 \pm 0.26$ & $(98.4)$ \\
\hline 63 & $9.59 \pm 0.19$ & (97.5) & $9.75 \pm 0.31$ & (99.0) & $9.72 \pm 0.24$ & $(98.7)$ \\
\hline 77 & $9.80 \pm 0.34$ & (99.2) & $9.76 \pm 0.15$ & (99.2) & $9.69 \pm 0.31$ & (98.5) \\
\hline 92 & $9.73 \pm 0.31$ & (98.8) & $9.85 \pm 0.11$ & $(100.1)$ & $9.79 \pm 0.21$ & (99.5) \\
\hline $\begin{array}{c}\% \text { remaining on day } 92 \\
\text { by linear regressiont }\end{array}$ & \multicolumn{2}{|l|}{97.4} & \multicolumn{2}{|l|}{99.2} & \multicolumn{2}{|c|}{100.0} \\
\hline $\begin{array}{l}\text { Lower limit of } 95 \% \mathrm{Cl} \text { for } \\
\% \text { remaining } \neq\end{array}$ & \multicolumn{2}{|l|}{93.7} & \multicolumn{2}{|l|}{96.1} & \multicolumn{2}{|c|}{95.4} \\
\hline \multicolumn{5}{|l|}{$4^{\circ} \mathrm{C}$ storage } & \multicolumn{2}{|c|}{ NA } \\
\hline 0 & $9.84 \pm 0.10$ & & $9.84 \pm 0.10$ & & & \\
\hline 7 & $9.56 \pm 0.19$ & $(97.2)$ & $9.56 \pm 0.34$ & $(97.2)$ & & \\
\hline 14 & $10.05 \pm 0.27$ & $(102.2)$ & $9.90 \pm 0.23$ & (100.6) & & \\
\hline 21 & $9.90 \pm 0.24$ & $(100.6)$ & $9.77 \pm 0.30$ & (99.3) & & \\
\hline 28 & $9.86 \pm 0.25$ & $(100.2)$ & $10.00 \pm 0.20$ & (101.6) & & \\
\hline 42 & $9.79 \pm 0.26$ & (99.5) & $9.82 \pm 0.18$ & (100.5) & & \\
\hline 63 & $9.63 \pm 0.33$ & (97.9) & $9.85 \pm 0.39$ & $(100.2)$ & & \\
\hline 77 & $9.68 \pm 0.19$ & (98.4) & $9.73 \pm 0.26$ & (98.9) & & \\
\hline 92 & $9.73 \pm 0.16$ & (98.9) & $9.61 \pm 0.16$ & (97.7) & & \\
\hline $\begin{array}{c}\% \text { remaining on day } 92 \\
\text { by linear regressiont }\end{array}$ & 98.4 & & 99.0 & & & \\
\hline $\begin{array}{l}\text { Lower limit of } 95 \% \mathrm{Cl} \text { for } \\
\% \text { remaining } \neq\end{array}$ & 94.7 & & 95.5 & & & \\
\hline
\end{tabular}

$\mathrm{Cl}=$ confidence interval, $\mathrm{NA}=$ not applicable, SD = standard deviation.

*Nominal concentration: $10.0 \mathrm{mg} / \mathrm{mL}$. Mean values based on 3 samples analyzed in duplicate. Percent remaining relative to measured concentration on day 0 .

†Calculated from concentration on day 92 as determined by linear regression and concentration observed at time 0 , according to the following formula: (concentration at day $92 \div$ concentration at time 0 ) $\times 100$.

$\neq$ Calculated from lower limit of $95 \% \mathrm{Cl}$ of the slope of the curve relating concentration to time, determined by linear regression, according to the following formula: (lower limit of $95 \% \mathrm{Cl}$ of concentration at day $92 \div$ concentration at time 0 ) $\times 100$.

Mary H H Ensom, BS(Pharm), PharmD, FASHP, FCCP, FCSHP

Clinical Pharmacy Specialist

Diane Décarie, BSC

Research Consultant

Department of Pharmacy

Children's and Women's Health Centre of British Columbia

Vancouver, British Columbia
Mary Ensom is also a Professor, Faculty of Pharmaceutical Sciences, and Distinguished University Scholar, The University of British Columbia, Vancouver, British Columbia.

Funding: This study was funded by an unrestricted educational grant from Medisca Pharmaceutique Inc.

Competing interests: Other than grant support, no competing interests were declared. 